\title{
Evaluation of the inhibition of carbohydrate hydrolysing enzymes, antioxidant activity and polyphenolic content of extracts of ten African Ficus species (Moraceae) used traditionally to treat diabetes
}

\author{
Oyinlola O Olaokun ${ }^{1,3}$, Lyndy J McGaw ${ }^{1}$, Jacobus N Eloff ${ }^{1}$ and Vinny Naidoo ${ }^{1,2^{*}}$
}

\begin{abstract}
Background: Some Ficus species have been used in traditional African medicine in the treatment of diabetes. The antidiabetic potential of certain species has been confirmed in vivo but the mechanism of activity remains uncertain. The aim of this study was to determine the activity and to investigate the mechanism of antidiabetic activity of ten selected Ficus species through inhibition of a-amylase and a-glucosidase activity, and the possible relationship between these activities, the total polyphenolic content and the antioxidant activity.

Methods: Dried acetone leaf extracts were reconstituted with appropriate solvents and used to determine total polyphenolic content antioxidant activity, a-amylase and a-glucosidase inhibitory activity.

Results: The crude acetone extract of $F$. lutea had the highest polyphenolic content $(56.85 \pm 1.82 \mathrm{mg}$ GAE/g of dry material) and the strongest antioxidant activity with a TEAC value of $4.80 \pm 0.90$. The antioxidant activity of the acetone extracts of the Ficus species may not be ascribed to total polyphenolic content alone. The crude extract at a concentration of $0.5 \mathrm{mg} / \mathrm{ml}$ of F. lutea $(64.3 \pm 3.6 \%)$ had the best a-glucosidase (sucrase) inhibitory activity. The EC50 of F. lutea $(290 \pm 111 \mu \mathrm{g} / \mathrm{ml})$ was not significantly different from that of $F$. sycomorus $(217 \pm 69 \mu \mathrm{g} / \mathrm{ml})$. The a-amylase inhibitory activity of $F$. lutea $(95.4 \pm 1.2 \%)$ at a concentration of $1 \mathrm{mg} / \mathrm{ml}$ was the highest among the Ficus species screened. The EC50 for F. lutea $(9.42 \pm 2.01 \mu \mathrm{g} / \mathrm{ml})$, though the highest, was not significantly different $(p<0.05)$ from that of F. craterostoma and F. natalensis. It was apparent that the crude acetone extract of $F$. lutea is a partially non-competitive inhibitor of a-amylase and a-glucosidase. Based on correlation coefficients polyphenolics may be responsible for a-glucosidase activity but probably not for a-amylase activity.

Conclusion: Antidiabetic activity potential via inhibition of a-amylase and a-glucosidase was discovered in Ficus lutea which has not been previously reported. The acetone extract of the leaves was high in total polyphenolic content and antioxidant activity, and was a potent inhibitor of a-amylase activity. Research is underway to isolate the active compound(s) responsible for the antidiabetic activity and to confirm the in vitro antidiabetic activity and to investigate in vitro toxicity.
\end{abstract}

Keywords: African Ficus species, Ficus lutea, Diabetes, a-amylase inhibitory activity, a- glucosidase inhibitory activity, Antioxidant activity, Polyphenol content

\footnotetext{
* Correspondence: vinny.naidoo@up.ac.za

'Phytomedicine Programme, Department of Paraclinical Sciences, University

of Pretoria, Private Bag X04, Onderstepoort 0110, South Africa

${ }^{2}$ Biomedical Research Centre, Faculty of Veterinary Sciences, University of

Pretoria, Onderstepoort 0110, South Africa

Full list of author information is available at the end of the article
} 


\section{Background}

Diabetes mellitus is an endocrine disease characterised by chronic hyperglycaemia with the disturbance of carbohydrate, fat and protein metabolism resulting from defects in insulin secretion, insulin action or both [1], and is typically associated with the failure of pancreatic $\beta$-cells. There are two major types of diabetes mellitus - type 1 and type 2 . In type 1 diabetes, or insulin dependent diabetes mellitus, the body has little or no insulin secretory capacity and depends on exogenous insulin to prevent metabolic disorders and death. In type 2 diabetes, a non-insulin dependent diabetes mellitus, the body retains some endogenous insulin secretory capability; however, their insulin levels are low relative to their blood glucose levels and/or there is a measure of insulin resistance. Type 2 diabetes is the most prevalent form of the disease, accounting for $90-95 \%$ of cases [2,3].

Obesity, a sedentary lifestyle and a diet high in carbohydrate and fats are known risk factors for type 2 diabetes [4]. Globally, 171 million people were diagnosed with the disease in 2000 , and it has been predicted that the prevalence will grow to 366 million by 2030 if no intervention action is taken [5]. In sub-Saharan Africa the disease is also considered to be an important emerging disease partly due to changes in diet and lifestyle of the people (a highly refined diet coupled to reduced physical activity). This is brought about by westernization, urbanization and mechanization, i.e. the disease which was once associated with only the affluent has increased in prevalence from $1 \%$ to $20 \%$ while in South Africa it is $4 \%$ to $6 \%[3,6,7]$.

The prolonged hyperglycaemia that results in diabetic patients has been speculated to induce oxidative stress through the excessive generation of free radicals which may impair endogenous antioxidant defence [8]. The stabilization of blood glucose in diabetic patients is therefore important to prevent these hyperglycaemic complications [9]. The main therapeutic approach used to achieve this objective in the diabetic patient is to stimulate insulin release, increase the number of glucose transporters, inhibit gluconeogenesis or reduce the absorption of glucose [10]. Another therapeutic approach is to decrease the post-prandial hyperglycaemia [11], which is achieved with the enzyme inhibitors such as acarbose, voglibose and miglitol [12], which function by retarding the action of the gastrointestinal carbohydrate hydrolysing enzymes $\alpha$-amylase and $\alpha$-glucosidase. As a result, these substances delay carbohydrate digestion thereby decreasing the rate of glucose absorption, i.e. they blunt the post-prandial plasma glucose rise [13]. While effective, the gastrointestinal side effects of acarbose, which includes bloating, abdominal discomfort, diarrhoea, and flatulence make them less attractive as therapeutic agents. New anti-diabetic compounds which function by this mechanism but devoid of side effect are therefore desirable $[12,14]$.

Ficus is a genus of about 800 species of woody trees, shrubs and vines in the family Moraceae. They are found in all tropical habitat types, with about 100 species occurring in Africa and the surrounding islands [15]. Several species of the genus Ficus are used traditionally in a wide variety of ethnomedical remedies all over the world [16,17]. They have long been used in folk medicine as antidiabetic, anthelmintic, hypotensive, mild laxative, antirheumatic, digestive and anti-dysentery drugs $[18,19]$. From previous studies, these plants are known to have chemical constituents such as triterpenes, sterols, polyphenols, flavonoids, coumarins, alkaloids and other metabolites [20]. Polyphenolics are among the naturally occurring antidiabetic agents [21], which may function via various biological effects, of which one is the inhibition of hydrolysing enzymes [22]. Polyphenolic compounds are also one of the major constituents of medicinal compounds which act as free radical scavengers and antioxidants. Free radicals can react with biological molecules, leading to cell and tissue injuries and pathological events. Therefore the discovery of polyphenolic compounds with a potential to inhibit the activity of digestive enzymes and having excellent antioxidant activity with low adverse effects is important for the treatment of diabetes.

Twelve Ficus species have antidiabetic activity with glucose lowering activity in alloxan or streptozotocin induced diabetic laboratory animals. These are Ficus benghalensis L. [23], Ficus carica L. [24], Ficus racemosa L. [25], Ficus hispida L.f. [26], Ficus microcarpa L.f. [27], Ficus religiosa L. [28], Ficus thonningii Blume [29], Ficus glumosa Delile. [30] Ficus arnottiana (Miq.)Miq. [31], Ficus glomerata Roxb. [32], F. sycomorus L. [33] and F. deltoidea Jack [34]. Several Ficus species are also used traditionally to treat diabetes and other ailments (Table 1). Four of the Ficus species used in the current study have in vivo blood glucose lowering potential (Table 2). With the mechanism(s) of action being unknown, we investigate the $\alpha$-amylase and $\alpha$-glucosidase enzymes inhibitory activity of the acetone extracts of the leaves of the ten Ficus species (Table 1). Acetone was selected as extractant because it dissolves many hydrophilic and lipophilic components from plants [48], it is volatile and has low toxicity for use in bioassays [49]. Furthermore acetone does not extract sugars, which if present (as would be the case with water and alcoholic extracts) would complicate $\alpha$-amylase and $\alpha$-glucosidase inhibitory assays [50].

\section{Methods}

\section{Materials and chemicals}

Dimethyl sulphoxide (DMSO), acetone, methanol and Whatman No. 1 filter paper were purchased from Merck 
Table 1 Previous reports on the traditional uses of the selected Ficus species * F. religiosa is a naturalized exotic from China

\begin{tabular}{|c|c|c|c|c|c|}
\hline Species & Section & Sub-section & Parts used & Uses & Reference \\
\hline $\begin{array}{l}\text { F. capreifolia Delile } \\
\text { (sandpaper fig) }\end{array}$ & sycidium & - & Leaf, root & Infections, vulnerary schistosomiasis & [35] \\
\hline $\begin{array}{l}\text { F. cordata Thunb. } \\
\text { (Namaqua rock fig) }\end{array}$ & urostigma & urostigma & Bark stem & Treatment of diarrhoea, tuberculosis & {$[36]$} \\
\hline $\begin{array}{l}\text { F. craterostoma Mildbr. } \\
\& \text { Burret. (forest fig) }\end{array}$ & galoglychia & chlamydodorae & leaves & Treatment of stomach ache & {$[37]$} \\
\hline $\begin{array}{l}\text { F. glumosa Delile } \\
\text { (hair rock fig) }\end{array}$ & galoglychia & platyphyllae & Leaves, stem/bark & Treatment of skin diseases, diabetes, & {$[30,38]$} \\
\hline $\begin{array}{l}\text { F. lutea Vahl. } \\
\text { (giant-leaves fig) }\end{array}$ & galoglychia & galoglychia & Leaves, bark & Treatment of sores, boils, madness, rabies & {$[39,40]$} \\
\hline $\begin{array}{l}\text { F. natalensis Hochst. } \\
\text { (coastal strangler fig) }\end{array}$ & galoglychia & chlamydodorae & Leaf, fruits, bark & Treatment of skin infections, colic, venereal diseases & {$[18,38,41]$} \\
\hline $\begin{array}{l}\text { F. polita Vahl. } \\
\text { (heart-leaved fig) }\end{array}$ & galoglychia & caulocarpae & $\begin{array}{l}\text { Leaves, fruits, bark, } \\
\text { root }\end{array}$ & $\begin{array}{l}\text { Dyspepsia, infectious diseases, abdominal pain, } \\
\text { diarrhoea }\end{array}$ & [42] \\
\hline $\begin{array}{l}\text { F. religiosa } \mathrm{L} \text {. } \\
\text { (bo tree or sacred fig) }\end{array}$ & $*_{-}$ & $*_{-}$ & Leaves, bark/stem & $\begin{array}{l}\text { Treatment of ulcers, bacterial infections, asthma, } \\
\text { diabetes }\end{array}$ & {$[43,44]$} \\
\hline $\begin{array}{l}\text { F. sycomorus L. } \\
\text { (sycamore fig) }\end{array}$ & sycomorus & sycomorus & $\begin{array}{l}\text { Stem/bark, leaves, } \\
\text { root, }\end{array}$ & $\begin{array}{l}\text { Treatment of tumours, inflammation, mental madness, } \\
\text { pain, bacterial infections, diabetes }\end{array}$ & {$[45-47]$} \\
\hline $\begin{array}{l}\text { F. thonningii Blume } \\
\text { (bark-cloth fig) }\end{array}$ & galoglychia & chlamydodorae & Leaves, fruits & Bronchitis, urinary tract infection, epilepsy, diabetes & {$[41,47]$} \\
\hline
\end{tabular}

(South Africa). Folin-Ciocalteu reagent, gallic acid, sodium carbonate $\left(\mathrm{Na}_{2} \mathrm{CO}_{3}\right)$, potassium persulphate, ABTS [2, 2-azinobis-(3- ethylbenzothiazoline-6-sulfonic acid)], potato starch, porcine pancreatic $\alpha$ - amylase enzyme (type VI), sodium chloride, sodium phosphate, 3, 5dinitrosalicylic acid (DNS), sodium potassium tartrate, sodium hydroxide, acarbose, rat intestinal acetone powder, potassium phosphate, sucrose, TRIS (hydroxymethyl) aminomethane, hydrogen chloride $(\mathrm{HCl})$, the glucose oxidase kit (GAGO 20) and Trolox (a synthetic water soluble vitamin $\mathrm{E}$ analogue) were sourced from Sigma (South Africa). The absorbance measurements were read using a microtitre plate reader (Versamax, Molecular Devices).

\section{Plant material}

The leaves of ten Ficus species were collected at the Manie van der Schijff Botanical Garden (University of Pretoria), South Africa in February 2009, and voucher specimens were conserved in the HGWJ Schweikerdt Herbarium of the University of Pretoria. The names of

Table 2 Ficus species demonstrated to have blood glucose lowering potential in vivo

\begin{tabular}{lllll}
\hline Species & Part used & $\begin{array}{l}\text { Solvent for } \\
\text { extraction }\end{array}$ & $\begin{array}{l}\text { Effective dose } \\
\text { (mg/kg) in vivo }\end{array}$ & References \\
\hline Ficus glumosa & stem/bark & methanol & 65 & {$[30]$} \\
\hline Ficus religiosa & bark & water & 50 and 100 & {$[28]$} \\
\hline Ficus sycomorus & Stem/bark & methanol & 250 & {$[33]$} \\
\hline Ficus thonningii & stem/bark & ethanol & 120 and 240 & {$[29]$} \\
\hline
\end{tabular}

plant species and voucher numbers are as follow: Ficus capreifolia Delile - PRU 33124; Ficus cordata Thunb PRU 35501; Ficus craterostoma Warb. ex Mildbr. \& Burret.- PRU 48293; Ficus glumosa Delile - PRU 38554, Ficus lutea Vahl.- PRU 074568; Ficus natalensis Hochst PRU 078082; Ficus polita Vahl - PRU 35945; Ficus religiosa L. - PRU 115415; Ficus sycomorus L. - PRU 066173; and Ficus thonningii Blume - PRU 57036. The leaves were separated from the stems and dried at room temperature. The dried plant materials were milled to a fine powder in a Macsalab mill (Model 200 LAB, Eriez ${ }^{\odot}$ Bramley) and stored at room temperature in closed glass bottles in the dark until extracted.

\section{Preparation of plant extracts}

The powdered plant material (2 g) was extracted with acetone $(20 \mathrm{ml})$ in polyester centrifuge tubes using a shaker (Labotec model 20.2) at room temperature for $30 \mathrm{~min}$. The extracts were centrifuged and filtered through Whatman No. 1 filter paper. This procedure was repeated three times on the same plant material to ensure that all possible compounds were extracted. The filtered extracts of each species were transferred into pre-weighed glass vials and solvent was left to evaporate at room temperature under a stream of cold air. The percentage yield was expressed on the air-dried mass of the leaves. The dried crude acetone extracts obtained were dissolved in appropriate solvent and used for analyses of total polyphenolics, antioxidant activity and in vitro $\alpha$-amylase and $\alpha$-glucosidase inhibition. 


\section{Total polyphenolic content}

The amount of total polyphenolics was determined using the method described by Djeridane et al. [51]. This method depends on the reduction of Folin-Ciocalteu reagent (a $2 \mathrm{~N}$ phosphomolybdic-phosphotungstic reagent) by phenols to a mixture of blue oxides. The commercial reagent was diluted 10 -fold with double-distilled water. A standard curve was developed using gallic acid. Different concentrations of gallic acid were prepared in $80 \%$ methanol in a 96-well microtitre plate, and their absorbance immediately recorded at $760 \mathrm{~nm}$. The crude acetone extracts were dissolved in $80 \%$ methanol to a final concentration of $1 \mathrm{mg} / \mathrm{ml}$. The plant extract $(100 \mu \mathrm{l}$ of the $1 \mathrm{mg} / \mathrm{ml}$ ) was dissolved in $500 \mu \mathrm{l}$ (1/10 dilution) of the Folin-Ciocalteu reagent. After the addition of $1000 \mu \mathrm{l}$ of distilled water the mixture was allowed to stand for $1 \mathrm{~min}$ at room temperature, where after $1500 \mu \mathrm{l}$ of a $20 \% \mathrm{Na}_{2} \mathrm{CO}_{3}$ solution was added. The final mixture was shaken, followed by an incubation period of $1 \mathrm{~h}$ in the dark at room temperature. The absorbance of all samples was measured at $760 \mathrm{~nm}$. All analyses were performed in triplicate and repeated three times. The results are expressed in mg of gallic acid equivalent (GAE) per gram of dry weight of plant material.

\section{Trolox equivalent anti-oxidant capacity (TEAC)}

The total antioxidant activity was estimated using the Trolox equivalent capacity (TEAC) test [52]. In this assay, the relative capacity of antioxidant to scavenge the ABTS ${ }^{+}$ [2, 2-azinobis- (3-ethylbenzothiazoline-6-sulfonic acid)] radical compared to the antioxidant potency of Trolox (6hydroxyl-2,5,7,8-tetramethlchromane-2-carboxylic acid), a synthetic water soluble vitamin $\mathrm{E}$ analogue, was measured.

The $\mathrm{ABTS}^{+}$radical was produced by reacting $7 \mathrm{mM}$ ABTS aqueous solution with $2.4 \mathrm{mM}$ potassium persulphate in the dark for $12-16 \mathrm{~h}$ at room temperature. Prior to assay, the pre- formed ABTS ${ }^{+}$radical was diluted in methanol (about 1:89 v/v) and equilibrated to give an initial absorbance $(\mathrm{Ai})$ of $0.700( \pm 0.02)$ at $734 \mathrm{~nm}$. The crude acetone extracts were made up in methanol to a concentration of $0.0625 \mathrm{mg} / \mathrm{ml}$ to $1 \mathrm{mg} / \mathrm{ml}$ and the Trolox was made up to a concentration of $0.0625 \mathrm{mg} / \mathrm{ml}$ to $0.5 \mathrm{mg} / \mathrm{ml}$ in methanol. The crude acetone extract or Trolox standard $(20 \mu \mathrm{l})$ was added to the $\mathrm{ABTS}^{+}$radical $(180 \mu \mathrm{l})$ and the mixture allowed to react for 6 minutes, and the absorbance (A) read at $734 \mathrm{~nm}$ in a spectrophotometer at one- minute intervals. Appropriate solvent blanks were included in each assay. The percentage change in absorbance was calculated for each concentration of extracts and Trolox. To calculate the TEAC, the gradient of the plot of the percentage inhibition of absorbance versus concentration plot for the extract under investigation is divided by the gradient of the plot for Trolox [52]. As a result, the TEAC of a substance is a ratio value and has no unit. All assays were carried out in triplicate and repeated three times. The percentage change in absorbance (A) was measured as follows;

$$
\begin{aligned}
\% \text { change in } \mathrm{A}= & \left(\frac{\mathrm{A}_{\mathrm{i}} \mathrm{ABTS}^{+}(734 \mathrm{~nm})-\mathrm{New} \text { mean } \mathrm{A} \mathrm{ABTS}^{+}}{\mathrm{A}_{\mathrm{i}} \mathrm{ABTS}^{+}(734 \mathrm{~nm})}\right) \\
& \times 100
\end{aligned}
$$

\section{a-Amylase inhibition assay}

An adapted $\alpha$-amylase inhibition assay as described by Ali et al. [50] was utilised. The dried crude acetone extracts were re-dissolved in DMSO to a concentration of $20 \mathrm{mg} /$ $\mathrm{ml}$ and used for the $\alpha$-amylase inhibition assay. Ice cold porcine pancreatic $\alpha$-amylase solution $(200 \mu \mathrm{l})$ at $4 \mathrm{unit} / \mathrm{ml}$ (type VI) was pre-incubated with $40 \mu \mathrm{l}$ of crude acetone extracts and $160 \mu \mathrm{l}$ of distilled water, and mixed in a screw-top plastic tube. The reaction was started by the addition of $400 \mu \mathrm{l}$ of potato starch $(0.5 \%, \mathrm{w} / \mathrm{v})$ in $20 \mathrm{mM}$ phosphate buffer ( $\mathrm{pH}$ 6.9) containing $6.7 \mathrm{mM}$ sodium chloride, and thereafter incubated at $25^{\circ} \mathrm{C}$ for $3 \mathrm{~min}$. Final concentrations in the incubation mixture were plant extract $(1 \mathrm{mg} / \mathrm{ml}), 0.25 \%(\mathrm{w} / \mathrm{v})$ starch and $1 \mathrm{unit} / \mathrm{ml}$ enzyme. An aliquot of the mixture $(200 \mu \mathrm{l})$ was removed and placed into a separate tube containing $100 \mu \mathrm{l}$ DNS colour reagent solution (96 mM 3, 5-dinitrosalicylic acid, 5.31 M sodium potassium tartrate in $2 \mathrm{M} \mathrm{NaOH}$ ) and placed into an $85^{\circ} \mathrm{C}$ water bath. After $15 \mathrm{~min}$, this mixture was removed from the water bath, cooled and diluted with $900 \mu$ ldistilled water. $\alpha$-Amylase activity was determined by measuring the remaining starch content by measuring the absorbance of the mixture at $540 \mathrm{~nm}$. Control incubations, representing $100 \%$ enzyme activity were conducted by replacing the plant extract with DMSO $(40 \mu \mathrm{l})$. For the blanks (negative controls) the enzyme solution was replaced with distilled water and the same procedure was carried out as above. Acarbose was used as positive control (acarbose $1 \mathrm{mg} / \mathrm{ml}$ : $\alpha$-amylase 1 unit $/ \mathrm{ml})$. The $\alpha$-amylase inhibition activity was expressed as;

$$
\begin{aligned}
\% \text { Inhibition } & =100 \times\left(\frac{\Delta \mathrm{A}_{\text {Control }}-\Delta \mathrm{A}_{\text {Sample }}}{\Delta \mathrm{A}_{\text {Control }}}\right) \\
\Delta \mathrm{A}_{\text {Control }} & =\mathrm{A}_{\text {Test }}-\mathrm{A}_{\text {Blank }} \\
\Delta \mathrm{A}_{\text {Sample }} & =\mathrm{A}_{\text {Test }}-\mathrm{A}_{\text {Blank }}
\end{aligned}
$$

\section{a- Glucosidase inhibition assay}

A commercial rat intestine acetone powder was purchased and used to prepare enzyme solution according to the method of Oki et al. [53] with slight modifications. In brief, rat intestinal acetone powder $(25 \mathrm{mg} / \mathrm{ml})$ was homogenized in ice-cold $50 \mathrm{mM}$ phosphate buffer. After centrifugation at $6000 \times \mathrm{g}$ for $15 \mathrm{~min}$, the clear supernatant obtained was used as the enzyme solution for determining $\alpha$-glucosidase activity. 
The rat intestinal sucrase inhibitory activity was determined using the method of Bhandari et al. [54], with a slight modification. Sucrose $(200 \mu \mathrm{l}$ of a $56 \mathrm{mM}$ solution) in $0.1 \mathrm{M}$ potassium phosphate buffer ( $\mathrm{pH} 7$ ) was mixed with $100 \mu \mathrm{l}$ of crude acetone extracts $(2.5 \mathrm{mg} / \mathrm{ml})$ in $50 \%$ aqueous dimethyl sulphoxide (DMSO) in a test tube. After pre-incubation at $37^{\circ} \mathrm{C}$ for $5 \mathrm{~min}, 200 \mu \mathrm{l}$ of rat intestinal $\alpha$-glucosidase solution prepared as described above was added. Whereas $100 \mu \mathrm{l}$ DMSO (50\%) was used in place of the plant extract to represent $100 \%$ enzyme activity, Acarbose $(0.1 \mathrm{mg} / \mathrm{ml})$ was used as the positive control and for the blanks (negative controls) the enzyme solution was replaced with distilled water and the same procedure was carried out as above. Final concentrations in the incubation mixture for plant extracts were $0.5 \mathrm{mg} / \mathrm{ml}$ and $0.02 \mathrm{mg} / \mathrm{ml}$ for acarbose.

After thoroughly mixing, the test sample, solvent and positive control test tubes were incubated at $37^{\circ} \mathrm{C}$ for $20 \mathrm{~min}$ and then the reaction was stopped by adding $750 \mu \mathrm{l}$ of $2 \mathrm{M}$ Tris-HCl buffer ( $\mathrm{pH}$ 6.9). The amount of liberated glucose was determined by the glucose oxidase method using a commercial test kit (Sigma GAGO 20) according to the manufacturer's instructions. The absorbance of the wells was measured at $540 \mathrm{~nm}$ and the inhibitory activity was calculated using the following formula:

$$
\begin{aligned}
\% \text { Inhibition } & =100 \times\left(\frac{\Delta \mathrm{A}_{\text {Control }}-\Delta \mathrm{A}_{\text {Sample }}}{\Delta \mathrm{A}_{\text {Control }}}\right) \\
\Delta \mathrm{A}_{\text {Control }} & =\mathrm{A}_{\text {Test }}-\mathrm{A}_{\text {Blank }} \\
\Delta \mathrm{A}_{\text {Sample }} & =\mathrm{A}_{\text {Test }}-\mathrm{A}_{\text {Blank }}
\end{aligned}
$$

\section{Kinetics of inhibition against $\alpha$ - amylase and $\alpha$ - glucosidase activities}

The kinetics of inhibition of the crude acetone extract of F. lutea against $\alpha$ - amylase and $\alpha$-glucosidase activities were measured by increasing substrate concentrations of starch $(0.016 \%-0.5 \%)$ and sucrose $(7 \mathrm{mM}-56 \mathrm{mM})$ respectively in the absence and presence of extract of $F$. lutea at concentrations of $25-100 \mu \mathrm{g} / \mathrm{ml}$ for $\alpha$-amylase inhibitory assay and $62.5-250 \mu \mathrm{g} / \mathrm{ml}$ for $\alpha$-glucosidase inhibitory assay. The type of inhibition was determined by Lineweaver-Burk double reciprocal plot analysis of the data, which was calculated from the result according to Michaelis-Menten kinetics [11].

\section{Calculation of EC50}

A dose response effect was conducted on $\alpha$ - amylase and $\alpha$-glucosidase for the extracts. The concentrations of extracts used ranged from 16 to $500 \mu \mathrm{g} / \mathrm{ml}$. The concentration of extract that inhibited $50 \%$ of the enzyme activity under assay conditions was defined as the effective concentration (EC50) and this was established using the programme Kinetica 5 (Thermo). The concentration response relationship was plotted and fitted to a Hill's model. The model was described by the following equation; $y=\frac{y_{\max } x^{\alpha}}{c^{\alpha}+x^{\alpha}}$. The EC50 concentrations attained were used for comparison of the potency of the various crude acetone plant extracts.

\section{Statistical analysis}

All experiments were performed in triplicate and repeated three times to yield nine dose- response curves. Data are presented as the mean \pm standard error of mean (S.E.M.). Statistical significances were evaluated by one-way analysis of variance (ANOVA) and student's $t$-test, with post hoc analysis using the Bonferroni corrected $t$-test. $P$-values less than 0.05 were considered to be significant.

\section{Results}

\section{Extraction of plant material}

Ten Ficus species were selected on the basis of availability and were extracted with acetone. In Table 3, the percentage yields of crude acetone extracts of the ten Ficus species are reported. The percentage yield ranged from $2.32 \%$ to $3.70 \%$ among the leaf extracts where the extract of F. lutea had the highest yield (3.70\%), followed by F. polita (3.15\%). The extracts of F. natalensis $(2.35 \%)$ and $F$. capreifolia had the lowest yields (2.32\%).

\section{Total polyphenol content and antioxidant activity}

The total polyphenol content of the crude acetone extracts of the ten Ficus species has highly variable (Table 3), with a range of 4.64 to $56.85 \mathrm{mg}$ GAE/g dry weight of plant. When the total polyphenol content of

Table 3 Percentage yield, total polyphenol content and antioxidant activity of crude acetone extracts of leaves of ten Ficus species

\begin{tabular}{llll}
\hline Species & Yield (\%) & $\begin{array}{l}\text { a Total polyphenol } \\
\text { (mg GAE/g dry weight) }\end{array}$ & $\begin{array}{l}\text { ab Antioxidant } \\
\text { activityTEAC }\end{array}$ \\
\hline Ficus capreifolia & 2.32 & $4.73 \pm 0.26^{\mathrm{c}}$ & $0.34 \pm 0.05^{\mathrm{c}}$ \\
\hline Ficus cordata & 2.65 & $8.23 \pm 1.00^{\mathrm{d}}$ & $0.27 \pm 0.03^{\mathrm{c}}$ \\
\hline Ficus craterostoma & 2.60 & $9.80 \pm 0.93^{\mathrm{d}}$ & $0.66 \pm 0.06^{\mathrm{d}}$ \\
\hline Ficus glumosa & 2.60 & $19.24 \pm 0.79^{\mathrm{e}}$ & $1.29 \pm 0.30^{\mathrm{e}}$ \\
\hline Ficus lutea & 3.70 & $56.85 \pm 1.82^{\mathrm{f}}$ & $4.80 \pm 0.90^{\mathrm{f}}$ \\
\hline Ficus natalensis & 2.35 & $4.75 \pm 0.92^{\mathrm{c}}$ & $0.69 \pm 0.08^{\mathrm{d}}$ \\
\hline Ficus polita & 3.15 & $8.04 \pm 0.52^{\mathrm{d}}$ & $0.31 \pm 0.06^{\mathrm{c}}$ \\
\hline Ficus religiosa & 2.45 & $5.40 \pm 0.35^{\mathrm{c}}$ & $0.59 \pm 0.18^{\mathrm{c}}$ \\
\hline Ficus sycomorus & 2.60 & $12.33 \pm 0.26^{\mathrm{e}}$ & $1.91 \pm 0.19^{\mathrm{e}}$ \\
\hline Ficus thonningii & 2.40 & $4.64 \pm 0.48^{\mathrm{c}}$ & $0.77 \pm 0.06^{\mathrm{d}}$ \\
\hline
\end{tabular}

Values are means of triplicate determinations done three times $(n=9) \pm$ standard error;

${ }^{\mathrm{b}}$ Antioxidant activity (Trolox equivalent antioxidant capacity).

$c, d, e, f$ No significant difference between extracts with same value, but significant difference $p<0.05$ between different values. 
each extract was compared, the extract of $F$. lutea $(56.85 \pm 1.82 \mathrm{mg} / \mathrm{g})$ was found to have a remarkably higher content $(p \square 0.001)$ followed in decreasing order by extracts of $F$. glumosa and $F$. sycomorus with total polyphenol content of $19.24 \pm 0.79$ and $12.33 \pm 0.26 \mathrm{mg} \mathrm{GEA} / \mathrm{g}$ dry weight of plant respectively. The extracts with the lowest values in decreasing order were $F$. natalensis, $F$. capreifolia and $F$. thonningii with total phenolic content of $4.75 \pm 0.92,4.73 \pm 0.26$ and $4.64 \pm 0.28 \mathrm{mg}$ GAE/g dry weight of plant respectively.

The antioxidant activities of the extracts, expressed as Trolox equivalent antioxidant capacity (TEAC) are listed in Table 3. The crude acetone extracts of the ten Ficus species had different antioxidant capacities (Table 3). The total antioxidant activity for the ten Ficus species varied widely from $4.80 \pm 0.90$ to $0.27 \pm 0.03$ TEAC under the assay conditions. The antioxidant activity of the extract of $F$. lutea $(4.80 \pm 0.90$ TEAC) was significantly different $(p \square 0.001)$ when compared with that of the other extracts, followed by $F$. sycomorus and $F$. glumosa in decreasing order with antioxidant activity of $1.91 \pm 0.18$ and $1.29 \pm 0.30$ TEAC respectively. The extracts with the lowest TEAC in decreasing order were $F$. capreifolia, F. polita and F. cordata with $0.34 \pm 0.05$, $0.31 \pm 0.06$ and $0.27 \pm 0.03$ TEAC respectively. The correlation coefficient between total polyphenolic content and TEAC of the crude acetone extracts of the ten Ficus species $R^{2}$ was 0.50 .

\section{a-Amylase inhibitory activity of extracts of Ficus species}

The inhibitory activity of the crude acetone extracts of the ten Ficus species are presented in Table 4. The extract of $F$. lutea had the highest inhibitory potential with activity of $95.4 \pm 1.2 \%$ inhibition at $1 \mathrm{mg} / \mathrm{ml}$. This was followed by the extract of $F$. glumosa with $65.1 \pm 3.0 \%$ inhibition at the same concentration while Acarbose, the positive control, had inhibitory activity of $96.7 \pm 0.3 \%$ at $0.04 \mathrm{mg} / \mathrm{ml}$. The extracts of the other Ficus species moderately inhibited $\alpha$-amylase with activity between $40 \%$ and $45 \%$, with the exception of the extracts of $F$. religiosa and $F$. thonningii which had poor inhibitory activities. The EC50s are presented in Table 4. The extract of $F$. lutea was most potent (EC50 of $9.42 \pm 2.01 \mu \mathrm{g} / \mathrm{ml}$ ) followed by F. craterostoma $(\mathrm{EC} 50=11.41 \pm 4.68 \mu \mathrm{g} / \mathrm{ml})$ and $F$. natalensis $(\mathrm{EC} 50=17.85 \pm 4.42 \mu \mathrm{g} / \mathrm{ml})$ with no significant difference present between them $(p<0.05)$. Acarbose was characterised by an EC50 of $0.04 \pm$ $0.03 \mu \mathrm{g} / \mathrm{ml}$. The correlation coefficient between total polyphenolic content and inhibition of $\alpha$-amylase activity by the extracts of the ten Ficus species $\mathrm{R}^{2}$ was 0.65 . Conversely, the correlation coefficient between antioxidant activity (TEAC) and inhibition of $\alpha$-amylase activity by the crude acetone extracts of the ten Ficus species $\mathrm{R}^{2}$ was 0.41 .
Table 4 The percentage inhibition of a-amylase activity $(1 \mathrm{mg} / \mathrm{ml}$ ) and concentration leading to $50 \%$ inhibition (EC50) of crude acetone extracts of the ten selected Ficus species

\begin{tabular}{lll}
\hline Species & (\%) $\mathbf{a}$ - amylase inhibition & EC50 $(\boldsymbol{\mu g} / \mathbf{m l})$ \\
\hline Ficus capreifolia & $43.8 \pm 3.3^{\mathrm{b}}$ & $>100$ \\
\hline Ficus cordata & $45.9 \pm 5.2^{\mathrm{b}}$ & $>100$ \\
\hline Ficus craterostoma & $48.3 \pm 1.6^{\mathrm{b}}$ & $11.41 \pm 4.68^{\mathrm{b}}$ \\
\hline Ficus glumosa & $65.1 \pm 3.0^{\mathrm{c}}$ & $>100$ \\
\hline Ficus lutea & $95.4 \pm 1.2^{\mathrm{d}}$ & $9.42 \pm 2.01^{\mathrm{b}}$ \\
\hline Ficus natalensis & $43.7 \pm 1.8^{\mathrm{b}}$ & $17.85 \pm 4.42^{\mathrm{b}}$ \\
\hline Ficus polita & $40.2 \pm 2.6^{\mathrm{b}}$ & $>100$ \\
\hline Ficus religiosa & $35.3 \pm 2.8^{\mathrm{b}}$ & $>100$ \\
\hline Ficus sycomorus & $40.0 \pm 2.8^{\mathrm{b}}$ & $>100$ \\
\hline Ficus thonningii & $37.6 \pm 2.7^{\mathrm{b}}$ & $>100$ \\
\hline Acarbose & $96.7 \pm 0.3^{\mathrm{b}}$ & $0.04 \pm 0.03$ \\
\hline
\end{tabular}

${ }^{\mathrm{a}} \%$ a-amylase inhibitory activity of crude acetone extracts of ten South African Ficus species $(1 \mathrm{mg} / \mathrm{ml}$ ) and control (acarbose) $(0.04 \mathrm{mg} / \mathrm{ml})$. Results expressed as $\%$ mean \pm SEM $(n=9)$. ${ }^{b, c, d}$ No significant difference between extracts with same value, but significant difference $p^{<} 0.05$ between different values.

\section{a-Glucosidase inhibitory activity of extracts of Ficus} species

The crude acetone extracts of the ten Ficus species were generally weak inhibitors of $\alpha$ - glucosidase activity (Table 5), with only F. lutea demonstrating inhibitory activity of $64.3 \pm 3.6 \%$ at a concentration of $0.5 \mathrm{mg} / \mathrm{ml}$ (Significantly different $(p \square 0.05)$ to the other extracts). Acarbose (positive control) was a potent inhibitor of $\alpha$ glucosidase $(84.8 \pm 1.7 \%)$ at a concentration of $0.02 \mathrm{mg} /$ $\mathrm{ml}$. The EC50s for the inhibitory activity is presented in

Table 5 The percentage inhibition of a-glucosidase activity $(0.5 \mathrm{mg} / \mathrm{ml})$ and concentration leading to $50 \%$ inhibition (EC50) of crude acetone extracts of ten Ficus species

\begin{tabular}{|c|c|c|}
\hline Species & (\%) a-glucosidase inhibition ${ }^{a}$ & EC50 $(\mu \mathrm{g} / \mathrm{ml})$ \\
\hline Ficus capreifolia & $24.3 \pm 1.7^{b}$ & $>1000$ \\
\hline Ficus cordata & $22.0 \pm 3.6^{b}$ & $>1000$ \\
\hline Ficus craterostoma & $28.2 \pm 7.0^{\mathrm{b}}$ & $>1000$ \\
\hline Ficus glumosa & $38.7 \pm 6.5^{b}$ & $>1000$ \\
\hline Ficus lutea & $64.3 \pm 3.6^{c}$ & $290 \pm 111^{b}$ \\
\hline Ficus natalensis & $23.6 \pm 8.1^{b}$ & $>1000$ \\
\hline Ficus polita & $29.2 \pm 5.8^{b}$ & $>1000$ \\
\hline Ficus religiosa & $17.6 \pm 8.0^{\mathrm{b}}$ & $>1000$ \\
\hline Ficus sycomorus & $35.7 \pm 5.4^{\mathrm{b}}$ & $217 \pm 69^{b}$ \\
\hline Ficus thonningii & $25.3 \pm 5.0^{\mathrm{b}}$ & $>1000$ \\
\hline Acarbose & $84.8 \pm 1.7$ & $3.4 \pm 0.5$ \\
\hline
\end{tabular}

${ }^{a} \%$ a-glucosidase inhibitory activity of crude acetone extracts of ten South African Ficus species $(0.5 \mathrm{mg} / \mathrm{ml})$ and control (acarbose) $(0.02 \mathrm{mg} / \mathrm{ml})$. Results expressed as $\%$ mean \pm SEM $(n=9)$.

b,c. No significant difference between extracts with same value, but significant difference $p<0.05$ between different values. 
Table 5. The extract of $F$. sycomorus was most potent with an EC50 of $217 \pm 69 \mu \mathrm{g} / \mathrm{ml}$, followed closely by the extract of F. lutea $(290 \pm 111 \mu \mathrm{g} / \mathrm{ml})$, with no significant difference between them ( $p \square 0.05)$. The EC50 of Acarbose was $3.4 \pm 0.5 \mu \mathrm{g} / \mathrm{ml}$. The correlation coefficient between total polyphenolic content and inhibition of $\alpha$ glucosidase activity by the crude acetone extracts of the ten Ficus species $\mathrm{R}^{2}$ was 0.74 . In addition, the correlation coefficient between antioxidant activity (TEAC) and inhibition of $\alpha$-glucosidase activity by the crude acetone extracts of the ten Ficus species $\mathrm{R}^{2}$ was 0.67 .

\section{The enzyme kinetics of $a$ - amylase and $a$ - glucosidase inhibition by extract of $F$. lutea}

Analysis of the $\alpha$-amylase and $\alpha$-glucosidase kinetics by the crude acetone extract of $F$. lutea is shown in Figure 1. For the $\alpha$-amylase (Figure 1A) and $\alpha$-glucosidase (Figure 1B) inhibition by F. lutea, the intersection of the double reciprocal plot is seated at a point above the $+1 /[\mathrm{s}]$ axis, indicating that F. lutea acts as a partially non-competitive-type inhibitor of $\alpha$-amylase and $\alpha$ - glucosidase.

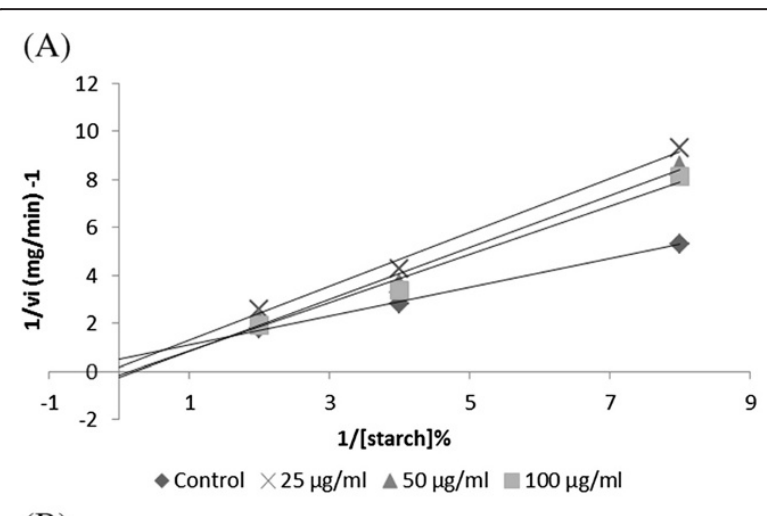

(B)

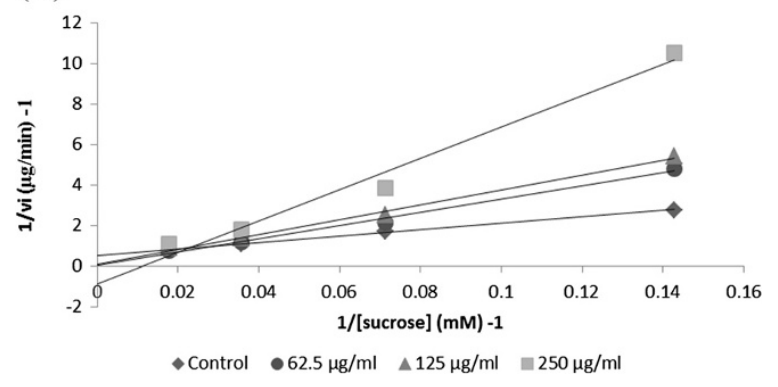

Figure 1 Lineweaver-Burk double reciprocal plots for kinetic analysis of the reaction of porcine pancreatic a-amylase with starch (\%) used as substrate (A) and rat intestinal a-glucosidase with sucrose $(\mathrm{mM})$ used as substrate $(B)$ in the absence and presence of extract of $F$. lutea.

\section{Discussion}

The most challenging goal in the management of type 2 diabetes mellitus is to achieve blood glucose levels as close to normal as physiologically possible [55]. With postprandial hyperglycaemia being the earliest metabolic abnormality detectable, modulation of this rise is an important tool in the management of the diabetic patient [56,57]. $\alpha$-Amylases are endoglucanases, which hydrolyse the internal $\alpha-1,4$ glucosidic linkages in starch, and $\alpha$ glucosidase (sucrase), one of the glucosidases located in the brush border surface membrane of intestinal cells, is a key enzyme for carbohydrate digestion and absorption. These enzymes have been recognized as therapeutic targets for modulation of postprandial hyperglycaemia. In addition, prolonged hyperglycaemia is an independent risk factor for the development of microvascular and macrovascular complications of diabetes mellitus which is mediated through oxidative stress $[55,58]$.

In this study the inhibitory effectiveness of the acetone extract of the leaves of ten Ficus species against the $\alpha$-amylase and $\alpha$-glucosidase enzymes were evaluated. As a secondary objective, the relationship between total polyphenolic content and antioxidant activity was also studied. For this study, a positive correlation between total polyphenolic content and inhibition of $\alpha$-amylase and $\alpha$-glucosidase activity was present with $R^{2}$ values of 0.65 and 0.74 respectively. This therefore indicates the likelihood of the polyphenols in the acetone extracts being partly responsible for the inhibition of the activity of the enzymes. The latter was not an unexpected finding as the polyphenolic extracts from a number of plants have been previously shown to be effective inhibitors of the intestinal $\alpha$-glucosidase and $\alpha$-amylase enzyme systems [59].

The extracts of ten Ficus species were evaluated for their potential to specifically inhibit activity of porcine pancreatic $\alpha$-amylase and rat small intestinal $\alpha$ glucosidase. The ten Ficus species were generally potent inhibitors of activity of the porcine pancreatic $\alpha$-amylase but weak inhibitors of activity of the rat small intestinal $\alpha$-glucosidase. Three of the four Ficus species with in vivo blood glucose lowering potential in previous studies (Table 2) were all weak inhibitors of the activity of $\alpha$-amylase and $\alpha$-glucosidase in vitro. While the reason for the difference could be due to the different compounds being extracted as a result of different solvents used in these studies, the more likely reason was that the glucose lowering potential of these plants may be due to non- $\alpha$-amylase or $\alpha$-glucosidase inhibitory activities, such as the stimulation of glucose uptake, the stimulation of insulin release or the inhibition of gluconeogenesis.

The fourth Ficus species (F. sycomorus) which is used traditionally by the Hausa and Fulani tribes of northern 
Nigeria to treat diabetes [33] together with known glucose lowering potential in vivo (Table 2) was a weak inhibitor of $\alpha$-amylase activity but a potent inhibitor of $\alpha$-glucosidase (sucrase) activity with an EC50 of $217 \pm$ $69 \mu \mathrm{g} / \mathrm{ml}$. We therefore believe that the glucose lowering potential demonstrated in vivo by the extract of $F$. sycomorus may be due to the inhibition of $\alpha$-glucosidase activity (sucrase). Some authors have shown that the extracts of other Ficus species such as F. racemose [60], F. benghalensis [61] and F. deltoidea [62] inhibit the activity of sucrase with an EC50 of $367 \pm 15.2 \mu \mathrm{g} / \mathrm{ml}$ and $239 \pm 14.3 \mu \mathrm{g} / \mathrm{ml}$ respectively for cold and hot water extract of F. racemosa, and $193 \pm 21.6 \mu \mathrm{g} / \mathrm{ml}$ and $141 \pm$ $22.1 \mu \mathrm{g} / \mathrm{ml}$ respectively for cold and hot water extract of F. benghalensis. This was in agreement with our results. Furthermore, studies also showed the activity of $\alpha$-amylase is inhibited with an EC50 of $0.94 \pm 0.15 \%$ and $0.58 \pm 0.15 \%$ respectively for the cold and hot water extracts of F. racemosa, [60] and, 4.4 and $125 \mu \mathrm{g} / \mathrm{ml}$ respectively for the cold and hot water extracts of $F$. benghalensis [63], this was also in agreement with our results.

Some studies have observed the potency with which polyphenols inhibited the activity of porcine pancreatic $\alpha$-amylase and rat small intestinal $\alpha$-glucosidase to be different $[59,64]$. Strawberry and raspberry extracts were the most effective inhibitors of $\alpha$-amylase followed by blueberry and blackcurrant. Although these extracts also inhibited rat intestinal $\alpha$ - glucosidase activity, the order of effectiveness was different than with $\alpha$-amylase. Blueberry and blackcurrant were the most effective followed by strawberry and raspberry [59]. Rat intestinal $\alpha$-glucosidase is generally weakly inhibited by many flavonoids, while flavonoids are often potent inhibitors of porcine pancreatic $\alpha$-amylase [64]. It is possible that the extracts of the Ficus species used in this study demonstrated potent $\alpha$-amylase inhibitory activity because they contain more of the flavonoid groups with the extract of $F$. lutea being the most potent.

Polyphenolic compounds may also be indirectly beneficial in disease by chelating metal ions [65] or activating the expression of antioxidant enzymes [66] or directly acting as antioxidants [67]. High total phenolic contents may not always translate to a high antioxidant activity. Pulido et al. [68] reported that antioxidant efficiency of the polyphenols seemed to depend on the position and extent of hydroxylation and conjugation. This was also observed in this study where the correlation between total polyphenolic content and antioxidant activity had an $\mathrm{R}^{2}$ value of 0.5 . We found that extracts of F. glumosa, $F$. sycomorus and $F$. lutea had good antioxidant activities and high total phenolic contents. Some authors have shown that F. glumosa [30], F. sycomorus [69] and F. lutea [39] have very good $\mathrm{DPPH}^{\cdot}$ scavenging activities with reported IC50 of $79.5 \pm 1.77 \mu \mathrm{g} / \mathrm{ml}$ and $11.9 \pm 0.3 \mu \mathrm{g} / \mathrm{ml}$ respectively for $F$. sycomorus and $F$. lutea, and this is in agreement with our results. Among these three Ficus species, the extract of $F$. lutea displayed the highest total polyphenolic content and the highest antioxidant activity.

In addition, the qualitative phytochemical analysis conducted (results not included) showed that tannin was one of the prominent phytochemicals contained in the crude acetone extract of $F$. lutea. Hagerman et al. [70] reported that the high molecular weight polyphenols (tannins) have the ability to quench free radicals $\left(\mathrm{ABTS}^{+}\right)$and their effectiveness depends on the molecular weight, the number of aromatic rings and the nature of the hydroxyl group substitutions. It is also possible that not all polyphenolic compounds possess $\mathrm{ABTS}^{+}$radical scavenging activities [71]. Free radical $\left(\mathrm{ABTS}^{+}\right)$scavenging of Ficus species may be due to the presence of high molecular weight polyphenols, such as catechins, pelargonidins and leucopelargonidin derivatives in addition to the flavonoids [72]. A study of the correlation between antioxidant activity and inhibition of $\alpha$-amylase and $\alpha$-glucosidase activity by the ten Ficus species had an $\mathrm{R}^{2}$ value of 0.41 and 0.67 respectively indicating that the polyphenolic compounds responsible for antioxidant activity may likely be responsible for the inhibition of $\alpha$-glucosidase activity but may not be responsible for the inhibition of $\alpha$-amylase activity. Some authors have demonstrated that compounds with potent antioxidant activity are also strong inhibitors of $\alpha$-glucosidase activity.

When studying the kinetics of inhibition, the extract of F. lutea showed partial non- competitive inhibition against porcine pancreatic $\alpha$-amylase and $\alpha$-glucosidase. A fully non- competitive inhibitor binds the enzyme substrate [ES] complex, not the free enzyme and affects the breakdown of the [ES] to form a product. Likewise, a partial non-competitive inhibitor binds to the enzyme-substrate complex but it is assumed that the inhibitor is released from the enzyme at the same time [ES] is broken down to the product [73]. This type of inhibition does occur where there are multiple inhibitors as will be the case for a crude extract of F. lutea [73]. Another study demonstrated that pure compounds such as D-xylose and (+)- catechin are un-competitive inhibitors of rat intestinal $\alpha$-glucosidase activity [53].

The results of this study revealed that the crude acetone extract of $F$. lutea is high in total polyphenolic content and antioxidant activity, and is a potent inhibitor of $\alpha$-amylase activity. This in vitro study has demonstrated that polyphenolic compounds present in F. lutea may likely be responsible for the inhibitory activity against the carbohydrate hydrolysing enzymes.

\section{Conclusion}

This study investigated the potential antidiabetic activity of ten South African Ficus species, focussing on effects on 
digestive enzymes, polyphenolic content and antioxidant activity. All acetone extracts of the ten Ficus species had $\alpha$-amylase and $\alpha$-glucosidase enzyme inhibitory activity. The crude acetone extract of $F$. lutea was the most active in all the assays. This is the first report of the antidiabetic potential of $F$. lutea in potentially lowering blood glucose levels in vitro. The crude acetone extract of F. lutea was more active in vitro than the crude acetone extracts of the three Ficus species that are reported to be used traditionally to treat diabetes. The activity that is responsible for the antidiabetic activity appears to reside in the polar fraction of the extract of $F$. lutea, so rural people should be able to extract the active compound(s) with water or alcohol. Research is underway to isolate the active compound responsible for the antidiabetic activity, to confirm the in vitro antidiabetic activity, and to investigate toxicity and efficacy in vivo.

\section{Competing interests}

The authors declare that they have no competing interests.

\section{Authors' contributions}

OOO carried out the study and wrote the manuscript; VN and JNE contributed to conception, design, analysis and interpretation of data, and LJM, JNE and VN assisted with and supervised the manuscript writing. All authors have read and approved the final manuscript.

\section{Acknowledgement}

The National Research Foundation (NRF) of South Africa provided funding and leaves were collected from the Manie van der Schijff Botanical Garden at the University of Pretoria.

\section{Author details}

${ }^{1}$ Phytomedicine Programme, Department of Paraclinical Sciences, University of Pretoria, Private Bag X04, Onderstepoort 0110, South Africa. ${ }^{2}$ Biomedical Research Centre, Faculty of Veterinary Sciences, University of Pretoria, Onderstepoort 0110, South Africa. ${ }^{3}$ Permanent address: Federal Institute of Industrial Research Oshodi (FIIRO), Ikeja, Nigeria.

Received: 30 October 2012 Accepted: 18 April 2013

Published: 4 May 2013

\section{References}

1. Anonymous: Definition, diagnosis and classification of diabetes mellitus and its complications. In Part 1: diagnosis and classification of diabetes mellitus. Geneva: Report of a WHO Consultation; 1999.

2. Kaneto H, Katakami N, Kawamori D, Miyatsuka T, Sakamota K, Matsuoka T-A, Matsuhisa M, Yamasaki Y: Involvement of oxidative stress in the pathogenesis of diabetes. Antioxid Redox Signal 2007, 9:355-366.

3. Jung M, Park M, Lee HC, Kang YH, Kang ES, Kim SK: Antidiabetic agents from medicinal plants. Curr Med Chem 2006, 13:1203-1218.

4. Jain S, Saraf S: Review on Type 2 diabetes mellitus-its global prevalence and therapeutic strategies. Diabetes and Metabolic Syndrome: Clinical Research and Reviews 2010, 4:48-56.

5. Wild S, Roglic G, Green A, Sicree R, King H: Global prevalence of diabetes Estimates for the year 2000 and projections for 2030. Diabetes Care 2004, 27:1047-1053.

6. Ogunbodede EO, Fatusi OA, Akintomide A, Kolawole K, Ajayi A: Oral health status in a population of Nigerian diabetics. J Contemp Dent Pract 2005, 6:75-84.

7. Deutschländer MS, van de Venter M, Roux S, Louw J, Lall N: Hypoglycaemic activity of four plant extracts traditionally used in South Africa for diabetes. J Ethnopharmacol 2009, 124:619-624.

8. Johansen JS, Harris AK, Rychly DJ, Ergul A: Oxidative stress and the use of antioxidants in diabetes: Linking basic science to clinical practice. Cardiovasc Diabetol 2005, 4(1):5. doi:10.1186/1475-2840-4-5.
9. Mai $\Pi$, Chuyen NV: Anti-hyperglycemic activity of an aqueous extract from flower buds of Cleistocalyx operculatus (Roxb.) Merr and Perry. Biosci Biotechnol Biochem 2007, 71:69-76.

10. Youn JY, Park HY, Cho KH: Anti-hyperglycemic activity of Commelina communis L: inhibition of alpha-glucosidase. Diabetes Res Clin Pract 2004, 66S:S149-S155.

11. Kim YM, Jeong YK, Wang MH, Lee WY, Rhee HI: Inhibitory effect of pine extract on alpha-glucosidase activity and postprandial hyperglycemia. Nutrition 2005, 21:756-761.

12. De Fronzo RA: Pharmacologic therapy for type 2 diabetes mellitus. Ann Intern Med 1999, 131:281-303.

13. Rhabasa-Lhoret $\mathrm{R}$, Chiasson JL: a-Glucosidase inhibitors. In International Textbook of Diabetes Mellitus, vol. 1. 3rd edition. Edited by Defronzo RA, Ferrannini E, Keen H, Zimmet P. UK.: John Wiley \& Sons Ltd.; 2004:901-914.

14. Moller DE: New drug targets for type 2 diabetes and the metabolic syndrome. Nature 2001, 414:821-827.

15. Serrato A, Ibarra-ManriqueZ G, Oyama K: Biogeography and conservation of the genus Ficus (Moraceae) in Mexico. J Biogeogr 2004, 31:475-485.

16. Hansson A, Zelada JC, Noriega HP: Re-evaluation of risks with the use of Ficus insipida latex as a traditional anthelmintic remedy in the Amazon. J Ethnopharmacol 2005, 98:251-257.

17. Koné WM, Atindehou KK, Terreaux C, Hostettmann K, Traoré D, Dosso M: Traditional medicine in North Côte-D'lvoire: Screening of 50 medicinal plants for antibacterial activity. J Ethnopharmacol 2004, 93:43-49.

18. Watt JM, Breyer-Brandwijk MG: Medicinal and poisonous plants of Southern and Eastern Africa. London: Livingstone Ltd; 1962:773-780.

19. Trivedi P, Hind S, Sharma RC: Preliminary phytochemical and pharmacological studies on Ficus racemosa. J Med Res 1969, 56:1070-1074.

20. Ramadan MA, Ahmad AS, Nafady AM, Mansour Al: Chemical composition of the stem bark and leaves of Ficus pandurata Hance. Nat Prod Res 2009, 23:1218-1230.

21. Andrade-Cetto A, Becerra-Jiménez J, Cárdenas-Vázquez R: Alpha-glucosidase inhibiting activity of some Mexican plants used in the treatment of type 2 diabetes. J Ethnopharmacol 2008, 116:27-32.

22. Mai TT, Thu NN, Tien PG, Van Chuyen N: Alpha-glucosidase inhibitory and antioxidant activities of Vietnamese edible plants and their relationships with polyphenol contents. J Nutr Sci Vitaminol 2007, 53:267-276.

23. Singh RK, Mehta S, Jaiswal D, Rai PK, Watal G: Antidiabetic effect of Ficus bengalensis aerial roots in experimental animals. J Ethnopharmacol 2009, 123:110-114.

24. Perez C, Dominguez E, Ramiro JM, Romero A, Campillo JE, Torres MD: A study on the glycaemic balance in streptozotocin-diabetic rats treated with an aqueous extract of Ficus carica (fig tree) leaves. Phytother Res 1996, 10:82-83.

25. Rao RB, Murugesan T, Sinha S, Saha BP, Pal M, Mandal SC: Glucose lowering efficacy of Ficus racemosa bark extract in normal and alloxan diabetic rats. Phytother Res 2002, 16:590-592.

26. Ghosh R, Sharatchandra KH, Rita S, Thokchom IS: Hypoglycaemic activity of Ficus hispida (bark) in normal and diabetic albino rats. Indian J Pharmacol 2004, 36:222-225.

27. Kumar KA, Maheshwari MU, Sivashanmugam AT, Devi VS, Prasanth NV, Ravi TK: Hypoglycemic effect of Ficus microcarpa leaves (Chinese banyan) on alloxan- induced diabetic rats. J Biol Scie 2007, 7(2):321-326.

28. Pandit R, Phahke A, Jagtap A: Antidiabetic effects of Ficus religiosa extract in streptozotocin-induced diabetic rats. J Ethnopharmacol 2010, 128:462-466.

29. Musabayane CT, Gondwe M, Kamadyaapa DR, Chuturgoon AA, Ojewole JAO: Effects of Ficus thonningii (Blume) [Moraceae] stem-bark ethanolic extract on blood glucose, cardiovascular and kidney functions of rats, and on kidney cell lines of the proximal (LLC-PK1) and distal tubules (MDBK). Ren Fail 2007, 29:389-397.

30. Madubunyi II, Onoja SO, Asuzu IU: In vitro antioxidant and in vivo antidiabetic potential of the methanolic extract of Ficus glumosa Del (Moraceae) stem bark in alloxan-induced diabetic mice. Comp Clin Pathol 2012, 21:389-394.

31. Mazumder PM, Farswan M, Parcha V: Hypoglycaemic effect of Ficus arnottiana Miq. bark extracts on streptozotocin induced diabetes in rats. Natural Product Radiance 2009, 8:478-482.

32. Kar A, Choudhary BK, Bandyopadhyay NG: Comparative evaluation of hypoglycaemic activity of some Indian medicinal plants in alloxan diabetic rats. J Ethnopharmacol 2003, 84:105-108. 
33. Adoum OA, Michael BO, Mohammad IS: Phytochemicals and hypoglycaemic effect of methanol stem-bark extract of Ficus sycomorus Linn (Moraceae) on allozan induced diabetic Wistar albino rats. Afr J Biotechnol 2012, 11(17):4095-4097.

34. Adam Z, Khamis S, Ismail A, Hamid M: Ficus deltoidea: a potential alternative medicine for diabetes mellitus. Evidence-Based Complementary and Alternative Medicine 2012. doi:10.1155/2012/632763.

35. Brink M: Ficus capreifolia Delile. In [Internet] Record from Protabase. Edited by Brink M, Achigan-Dako EG. Wageningen, Netherlands: PROTA (Plant Resources of Tropical Africa / Resources végétales de l'Afrique tropicale); 2010.

36. Kuete V, Ngameni B, Fotso Simo CC, Tankeu RK, Ngadjui BT, Meyer JJM, Lall $\mathrm{N}$, Kuiate JR: Antimicrobial activity of the crude extract and compounds from Ficus chlamydocarp and Ficus cordata (Moraceae). J Ethnopharmacol 2008, 120:17-24

37. Bhat RB, Jacobs TY: Traditional herbal medicine in Transkei. J Ethnopharmacol 1995, 48:7-12.

38. Hutchings A, Scott AH, Lewis G, Cunningham AB: Zulu medicinal plants. An inventory. Pietermaritzburg: University of Natal Press; 1996:352.

39. Marwah RG, Fatope MO, Al Mahrooqi R, Varma GB, Al Abadi H, Al-Burtamani SKS: Antioxidant capacity of some edible and wound healing plants in Oman. Food Chem 2006, 101:465-470.

40. Chifundera K: Livestock diseases and the traditional medicine in the Bushi area, Kive province, Democratic Republic of Congo. African Study Monographs 1998, 19:13-33.

41. Cousins D, Huffman MA: Medicinal properties in the diet of gorillas: an ethno- pharmacological evaluation. African Studies Monographs 2002, 23:65-89.

42. Kuete V, Kamga J, Sandjo LP, Ngameni B, Poumale HMP, Ambassa P, Ngadjui BT: Antimicrobial activities of the methanol extract, fractions and compounds from Ficus polita Vahl. (Moraceae). BMC Complement Altern Med 2011, 11:10. 1186/1472-6882-11-6.

43. Kirtikar J, Basu B: Ficus religiosa. In Indian Medicinal Plants, vol. 10, 2nd edition. Edited by Blatter E, Caius J, Mhaskar K. New Delhi: Oriental Enterprises; 2001:3200-3202.

44. Simmonds MSJ, Howes MJR: Plants used in the treatment of diabetes. In Traditional medicine for modern times - Antidiabetic Plants, 6th volume. Edited by Soumyanath A. UK: CRC Press/Taylor and Frances Group; 2006:19-82.

45. Lansky EP, Paavilainen HM, Pawlus AD, Newman RA: Ficus spp. (fig): ethnobotany and potential as anticancer and anti-inflammatory agents. J Ethnopharmacol 2008, 119:195-213.

46. Sandabe UK, Onyeyili PA, Chibuzo GA: Phytochemical screening and effect of aqueous extract of Ficus sycomorus L. (Moraceae) stembark on muscular activity in laboratory animals. J Ethnopharmaco/ 2006, 104:283-285.

47. Etuk EU, Bello SO, Isezuo SA, Mohammed BJ: Ethnobotanical survey of medicinal plants used for the treatment of diabetes mellitus in the north western region of Nigeria. Asian J Exp Biol Sci 2010, 1:55-59.

48. Kotze M, Eloff JN: Extraction of antibacterial compounds from Combretum microphyllum (Combretaceae). South African J Botany 2002, 66:62-70.

49. Eloff JN: Which extractant should be used for the screening and isolation of antimicrobial components from plants? J Ethnopharmacol 1998, 60:1-8.

50. Ali $\mathrm{H}$, Houghton PJ, Soumyanath A: Alpha-amylase inhibitory activity of some Malaysian plants used to treat diabetes; with particular reference to Phyllanthus amarus. J Ethnopharmacol 2006, 107:449-455.

51. Djeridane A, Yousfi M, Nadjemi B, Boutassouna D, Stocher P, Vidal N: Antioxidant activity of some Algerian medicinal plants extracts containing phenolic compounds. Food Chem 2006, 97:654-660.

52. Re-Roberta P, Proteggente N, Pannala A, Yang A, Rice-Evans C: Antioxidant activity applying an improved ABTS radical cation decolourization assay. Free Radic Biol Med 1999, 26:1231-1237.

53. Oki T, Matsui T, Osajima Y: Inhibitory effect of alpha-glucosidase inhibitor varies according to its origin. Journal of Agriculture and Food Chemistry 1999, 47:550-553.

54. Bhandari MR, Jong-Anurakkun N, Hong G, Kawabata J: Alpha-glucosidase and a- amylase inhibitory activities of Nepalese medicinal herb Pakhanbhed (Bergenia ciliata, Haw.). Food Chem 2008, 106:247-252.

55. Tiwari AK, Rao JM: Diabetes mellitus and multiple therapeutic approaches of phytochemicals: Present status and future prospects. Curr Sci 2002, 83:30-38.

56. Lebovitz HE: a-Glucosidase inhibitors as agents in the treatment of diabetes. Diabetes Review 1998, 6:132-145.
57. Baron AD: Postprandial hyperglycaemia and alpha-glucosidase inhibitors. Diabetes Res Clin Pract 1998, 40:51-55.

58. Kim J-S, Kwon C-S, Son K-H: Inhibition of alpha glucosidase and amylase by luteolin, a flavonoid. Biosci Biotechnol Biochem 2000, 64:2458-2461.

59. McDougall GJ, Shpiro F, Dobson P, Smith P, Blake A, Stewart D: Different polyphenolic components of soft fruits inhibit a-amylase and a-glucosidase. Journal of Agriculture and Food Chemistry 2005, 53:2760-2766.

60. Ahmed F, Urooj A: Effect of Ficus racemosa stem bark on the activities of carbohydrate hydrolysing enzymes: an in vitro study. Pharm Biol 2010, 48(5):518-523.

61. Ahmed F, Chavan S, Satish A, Punith Kumar R: Inhibitory activities of Ficus benghalensis bark against carbohydrate hydrolysing enzymes- An in vitro study. Pharmacognosy Journal 2011, 3(20):33-37.

62. Farsi E, Shafaei A, Hor SY, Khadeer Ahamed MB, Yam MF, Attitalla $H_{\text {, }}$ Asmawi $M Z$, Ismail Z: Correlation between enzymes inhibitory effects and antioxidant activities of standardised fractions of methanolic extract obtained from Ficus deltoidea leaves. Afr J Biotechnol 2011, 10(67):15184-15194.

63. Ponnusamy S, Ravindran R, Zinjarde S, Bhargava S, Kumar AR: Evaluation of traditional Indian antidiabetic medicinal plants for human pancreatic amylase inhibitory effect in vitro. Evidence-Based Complementary and Alternative Medicine 2011. doi:10, 1155/2011515647.

64. Tadera K, Minami Y, Takamatsu K, Matsuoka T: Inhibition of a-glucosidase and a- amylase by flavonoids. J Nutr Sci Vitaminol 2006, 52:149-152.

65. Brown JE, Khodr H, Hider RC, Rice-Evans CA: Structural dependence of flavonoid interactions with Cu2+ ions: implications for their antioxidant properties. Biochem J 1998, 330:1173-1178.

66. Carlsen H, Myhrstad MCW, Thoreson M, Moskaug JO, Blomhoff R: Berry intake increases the activity of the gamma-glutamyl cysteine synthetase promoter in transgenic reporter mice. J Nutr 2003, 133:2137-2140.

67. Rice-Evans CA, Miller NJ, Paganga G: Structure-antioxidant activity relationships of flavonoids and phenolic acids. Free Radic Biol Med 1996, 20:933-956.

68. Pulido R, Bravo L, Saura-Calixto F: Antioxidant activity of dietary polyphenols as determined by a modified ferric reducing/antioxidant power assay. Journal of Agriculture and Food Chemistry 2000, 48:3396-3402.

69. Abdel-Hameed E-SS: Total phenolic contents and free radical scavenging activity of certain Egyptian Ficus species leaf samples. Food Chem 2009, 114:1271-1277.

70. Hagerman AE, Riedl KM, Jones GA, Sovik KN, Ritchard NT, Hartzfeld PW, Riechel TL: High molecular weight plant polyphenolics (tannins) as biological antioxidants. Journal of Agriculture and Food Chemistry 1998, 46:1887-1892

71. Ivanova D, Gerova D, Chervenkov T, Yankova T: Polyphenols and antioxidant capacity of Bulgarian medicinal plants. J Ethnopharmacol 2005, 96:145-150.

72. Manian R, Anusuya N, Siddhuraju P, Manian S: The antioxidant activity and free radical scavenging potential of two different solvent extracts of Camellia sinensis (L.) O. Kuntz, Ficus bengalensis L. and Ficus racemosa L. Food Chem 2008, 107:1000-1007.

73. Dixon M, Webb EC: Enzyme inhibition and activation. In Enzymes. 3rd edition. New York: Academic Press Inc; 1999:332-380. Longman Group Ltd. London.

\section{doi:10.1186/1472-6882-13-94}

Cite this article as: Olaokun et al:: Evaluation of the inhibition of carbohydrate hydrolysing enzymes, antioxidant activity and polyphenolic content of extracts of ten African Ficus species (Moraceae) used traditionally to treat diabetes. BMC Complementary and Alternative Medicine 2013 13:94. 